\title{
22. Climate Change and Related Issues: Ian Castles' Contributions in Perspective
}

\author{
David Henderson
}

\section{Preface}

Ian Castles was a top Australian civil servant: the last two posts that he held were as Secretary of the Department of Finance and as Australian Statistician. He and I met in 1995, when we were both retired officials; and some years later, as recounted here, we became jointly involved, as close collaborators, on issues relating to climate change.

This chapter tells the story of our collaboration. In doing so, it develops two related themes. First, it brings out Ian's distinctive contributions in three related subject areas: inter-country measures of output and real expenditure; the continuing climate change debate; and - though this deserves a lot more space than I could give it here - what I call global salvationism, i.e., ways of thinking which combine confident over-pessimistic assessments and predictions with collectivist 'solutions'. Second, it offers a perspective on the evolution of the climate change debate over the past decade.

As compared with an earlier version, which has been widely circulated and posted on Andrew Montford's Bishop Hill blog, the text that follows has a few changes. In particular, I have inserted an extra paragraph in the next-to-final section. It takes account of further messages from Ian to me, following our last meeting in Canberra, which came to light after the earlier text had gone out.

\section{First involvement: How it came about}

Ian Castles became seriously engaged with climate change issues in the latter part of 2002, and over the rest of his life those issues came to form his main single professional concern. It was through him that I became involved myself, and as with him my involvement has proved to be a close and continuing one. For both of us, life took a new and unexpected course. Within it we acted not only as collaborators, which we already were, but also as joint authors. 
This new departure came about in an entirely unplanned and fortuitous way. In April 2002 a contested election took place for the Chair of the Intergovernmental Panel on Climate Change (the IPCC). As a result, Dr RK Pachauri was appointed to the position, which he still holds. In July he came to Canberra on an official visit, and Ian was invited to a meeting that was held for him. Ian used the occasion to tell Pachauri that the Special Report on Emissions Scenarios (SRES), prepared as an input to the IPCC's Third Assessment Report and published in 2000, was technically at fault, most notably in its handling of international comparisons of GDP. Pachauri invited Ian to write to him on the subject; and accordingly, on 6 August, Ian sent off a long and detailed letter. Three weeks later he sent a further supplementary letter, with an annex appended; and at the end of September Pachauri sent him a friendly holding response. Some time afterwards, Ian wrote to me to suggest that I should write a letter of my own to Pachauri to back him up, and on 28 October I duly complied. These actions of ours brought lasting consequences which neither of us had counted on.

\section{An existing alliance}

You might ask why it was that Ian wrote specifically to me, a resident of faraway London, to enlist my support for this new initiative on his part. The reason is straightforward. By the time he thus approached me, we had been friends, allies and informal collaborators for seven years or so. We first met in the early part of 1995, after John Stone, a former Secretary of the Australian Treasury, had suggested that I make sure to contact him during a coming visit of mine to Canberra; and it soon became apparent that we were kindred spirits. I was very much on Ian's side in what he described, in his opening letter to Pachauri, as 'my ongoing correspondence about the use and abuse of statistics in public debates about globalisation, poverty and the distribution of incomes both within and between countries'. In 1999 we worked in harness in connection with the ASSA conference of that year. In early 2000 I published a critique of the Human Development Report 1999, brought out by the UN Development Program; and in my opening paragraph I said that the article could be 'read in conjunction with a recently-published searching critique of the previous issue, the 1998 Report, by Ian Castles'.

Not only were we regularly exchanging emails at this time, but, at the beginning of 2002, shortly before Dr Pachauri came on the scene, we had discussed the idea of writing a book together. The book would have presented a critique of what I had come to call global salvationism, as reflected for example in the proceedings of successive mammoth UN conferences: in a draft outline that I sent to Ian, in March 2002, I used as one of the headings 'False consensus: dark visions and collectivist remedies'. We would have contrasted the history 
of failed prophecies of doom with the impressive actual record of economic performance, and argued the case for defending and enlarging the domain of competitive markets. We would have been writing as economic liberals, in the continental European sense of the term - 'classical liberals', if you like.

Now in that draft outline of the book, climate change issues went unmentioned; nor did Ian suggest that this was an omission on my part. Up to then, neither of us had taken a serious interest in the subject, nor had it been raised in our meetings or correspondence. This is worth noting, given that the issues had featured prominently on the policy agenda, national and international, since the late 1980s, and were about to feature prominently on the agenda of the 2002 UN Johannesburg summit meeting on sustainable development, which we had been proposing to review. For a period of 15 years or so, therefore, alike as serving officials and as retirees, we had both remained on the sidelines in the climate change debate. It was only in 2002 that this non-involvement on our part was brought to an end.

\section{A precipitating issue}

What had aroused Ian's concern, and mine too, was a specific technical issue. A position that we held in common, then and throughout, is to be found in the 1993 System of National Accounts (SNA), prepared by five international agencies and approved by those agencies' member governments. As Australian Statistician Ian had taken a close interest in this report; and its principal author, Peter Hill, had been one of my staff in my own last official role, as Head of what was then the Economics and Statistics Department of the OECD. In paragraph 38 of the opening chapter of the SNA it is laid down that:

When the objective is to compare the volumes of goods or services produced or consumed per head, data in national currencies must be converted into a common currency by means of purchasing power parities and not exchange rates ... Exchange rate converted data must not ... be interpreted as measures of the relative volumes of goods and services concerned.

In this connection, in the year 2000, Ian had already registered a notable success. Here is the story, as told in paragraph 3 of his first letter to Pachauri:

Following the release of the UNDP's Human Development Report 1999, I made extensive statistical criticisms of the treatment in that report of trends in global poverty and inequality. At the request of the 2000 meeting of the UN Statistical Commission, those criticisms were examined by a group of expert statisticians constituted as the Friends 
of the Chair of the Commission. The report of the group ... upheld my more serious criticisms. In particular, the Friends of the Chair ... held that HDR 1999 had made a "material error" (i.e., one which left the reader with "a fundamentally distorted view of the phenomenon being described") in relying on national aggregates converted into \$US at current exchange rates...

In the letter, Ian went on to record that: 'The HDR Office of the UNDP accepted the report, and has made major improvements in statistical presentation and reporting in subsequent issues of the HDR'.

The main single argument of our three letters to Pachauri was that the six scenario teams which had combined to produce the SRES, and the 40 scenarios which had been presented in the Report, had fallen into this same 'material error'. The scenarios offered projections of GDP and emissions over the period from 1990 to 2100, with the world economy divided into country groupings. For 1990, as the base year, they took as a point of departure figures for each group's GDP per head derived from national data which had been converted into a common measure using exchange rates; and the result of this, as with the 1999 HDR, was to overstate greatly the relative poverty of the poor countries. As Ian pointed out, in his second communication to Pachauri: '... average incomes in developing countries [were in reality] three or four times higher than the IPCC assumed'.

In projecting the growth of GDP per head to 2100, the scenarios provided, in varying degrees, for the closure, or substantial reduction, of this greatly overstated initial gap between rich and poor countries. We argued that in consequence these growth projections for poor countries were biased upward; and we inferred from this - though here we were mistaken, which it took us some time to realise - that a corresponding upward bias had entered into the projections of emissions from those countries. ${ }^{1}$

In voicing this criticism, our hope was that, following the encouraging precedent of the Human Development Report, the 'material error' would be recognised as such by the IPCC and its member governments, so that the required 'major improvements' would be made within the IPCC process. This hope, together

\footnotetext{
1 Our mistake arose because of a failure to think through the implications of an important point that Ian had made right from the start. In his second letter to Pachauri, he had noted that seriously underestimating the GDP of poor countries, through the use of exchange-rate-based comparative measures, brought with it a corresponding overestimate of comparative energy intensities: to quote the letter, 'The assumption of a huge margin of difference in energy intensity ... is false'. Hence the resulting SRES projections embodied, in varying degrees, twin errors which were largely offsetting. We were right to argue that, in so far as they built in the closure of an imaginary initial gap between rich and poor countries, projections of GDP growth in the latter group would be biased upward. We failed to note the corollary: that closing an equally imaginary gap in the energy intensity of those countries would damp down the effect of that GDP growth on emissions.
} 
with another aspiration which we formed, and which I will come to later, was doomed to disappointment. In outlining now the story of extended failure on our part, or at best heavily qualified success, I will start with the unexpected sequence of events that directly arose out of our letters to Pachauri.

\section{Developments in 2003-4}

Early in January 2003, Ian and I found ourselves, through an invitation which came from the IPCC Secretariat, at a meeting in Amsterdam of the Panel's Technical Group on Climate Impact Assessment. There we were able to meet some of the leading scenario authors, and to have extended discussions with them outside the main meeting; we were introduced to Dr Pachauri; and in the meeting itself, we were both invited - generously, I felt - to make fiveminute presentations of our own, despite the fact that what we had to say was unconnected with the meeting's actual agenda. (In my presentation, I noted that, confronted with these two strange old gentlemen, conference participants might find themselves reminded of Jack Lemmon and Walter Matthau). After we had respectively returned to Canberra and London, and in the light of the Amsterdam proceedings, Ian and I both wrote down, again separately, some further personal thoughts.

Between us we had now assembled, and posted on line, a curious swag of documents: three bulky letters to Pachauri; the two texts used as a basis for our respective five-minute presentations in Amsterdam; and twin post-Amsterdam reflections. We each emailed this collection to various friends and associates. Two of my recipients then reacted in ways that I had neither asked for nor expected, and which between them put the firm of Castles and Henderson truly on the map.

The first of these recipients was my friend Clive Crook, who was then Deputy Editor of The Economist: he offered to write up the issues on the 'Economics Focus' page of the paper. Of course I accepted with alacrity; and Clive's brilliant column put our arguments better than we had put them ourselves and gave them wide exposure. Moreover, the timing was perfect, since the column appeared in February 2003 during a plenary meeting of the IPCC, at which (as I learned) the complaint against us was made, not without justice, that 'The Economist is not a peer-reviewed journal'.

I also sent our swag to a journal editor whom at that stage I knew only by name: this was Sonja Boehmer-Christiansen, and her journal was Energy and Environment. To my great surprise, she offered to publish our collection, in full and without alteration. After consulting Ian, I replied that she was most welcome to do this, provided that she wrote right away to Dr Pachauri to invite him to 
arrange for the scenario authors to write a response to our criticisms, a response which she would guarantee to publish. She agreed, Pachauri agreed, and a (rather indignant) article by a group of 15 of the scenario builders duly appeared, alongside the set of miscellaneous documents by Castles and Henderson, in the same issue of the journal. ${ }^{2}$ In her 'editor's note' on our collection, Dr BoehmerChristiansen observed, you might think with some understatement, that 'This is not a standard journal article'. Few editors would have acted as she did.

In later issues of the same journal, there followed a second exchange of papers. Ian and I wrote a formal co-authored piece, while in turn a rather different team of scenario authors (18 in this case) published a further response to our arguments, which appeared in January 2004. ${ }^{3}$ Meanwhile Dr Pachauri himself had joined the debate. At the Ninth Conference of the Parties to the UN Framework Convention on Climate Change, in Milan on 8 December 2003, he gave a special press conference, the sole topic and purpose of which was a condemnation of our work. He described us as 'so-called "two independent commentators"', and said that we should be classed as purveyors of disinformation. His text was then posted, in prudently amended form, on the IPCC website.

Thus the scenario authors, and the IPCC directing circle, were far from accepting our critique. What is more, on this occasion, unlike that of the Human Development Report 1999, no support was forthcoming through the agency of the UN Statistical Commission. Looking through my records when preparing this paper, I came across the following email message from Ian, dated 12 June 2003. 'Dennis Trewin [Castles's successor as Australian Statistician] raised the CastlesHenderson issues at the UN Statistical Commission meeting in March, but was unable to win support from other countries'. This time, therefore, no Friends of the Chair were called in. We did win strong support from a former Canadian official statistician, Jacob Ryten, who published in Energy and Environment in mid-2004 an article for which I think I provided the title: it was headed 'MERs, PPPs and IPCC: Illusions and Reality'. ${ }^{4}$ In this piece he commented (367):

I cannot help being shocked by the contrasts between the [Scenario] Teams' bold assertions and peremptory dismissal of the arguments advanced by Castles and Henderson, and their manifest ignorance of the conceptual and practical issues involved in developing and using intercountry measures of economic product.

But Ryten was speaking only for himself, and I fear that his article gained little attention.

2 Energy and Environment, Vol .14, No. 2-3.

3 Our joint paper was entitled 'Economics, Emissions Scenarios and the Work of the 'IPCC', Energy and Environment, Vol. 14 No. 4, 2003. 'Emissions Scenarios: A Final Response', by Arnold Grubler and others, appeared in the same journal in Vol. 15 No. 1, 2004.

4 Energy and Environment, Vol. 15 No. 3, 2004. 


\section{Two fronts and our first misapprehension}

During this period and after, Ian and I were campaigning on two fronts. On the first of these, our target was the IPCC process - not just the SRES, but the process more broadly, as shown by the title of our second piece in Energy and Environment. Even in his opening letter to Pachauri, Ian had cited flaws in the treatment of international inequality in the 2001 report of the Panel's Working Group III, as well as in the SRES. In his Amsterdam text, as published, he wrote:

One might ask how many of the multitude of authors and reviewers of both documents, and the anonymous officials involved in the review process for these two reports, were aware of the existence of the SNA...

In that connection, I checked the extensive list of references in the SRES, to find that SNA 1993 made no appearance there: its existence may indeed have been unknown to the 53 members of the writing team and the 89 reviewers who are listed in the SRES. At one point in the report, revealingly, the concept of gross national product was misdefined.

Alongside the article by Ryten that I noted above, in mid-2004, Ian brought out a short piece in which he criticised the way in which, as he saw it, the IPCC process had evolved. He commented there (372) on a recently-published 340page report of an IPCC Expert Meeting, observing that: 'Most of the papers fall lamentably short of the minimum standards that could reasonably be expected in the publications of a scientific body'; and in the final sentence of this article (373), he referred to 'disturbing signs that the Panel's role in the assessment of climate change has now become subservient to its role in supporting a specific policy agenda'.

Both Ian and I had come to the view that the IPCC's treatment of statistical and economic issues was flawed, and that those responsible for it were not professionally representative. To remedy this situation, we advocated wider official participation. In writing to Pachauri, Ian had argued for the involvement of national statistical offices and the International Statistical Institute in making new emissions projections. In my own letter I wrote - again with the IPCC process as a whole in mind, not just the scenario exercise - that 'the central economic departments of state ... should likewise be taking an active part'. We emphasised this latter point in our first truly joint article, and it was echoed by Clive Crook in a further piece that he wrote in The Economist in late 2003.

The other front on which we continued to be engaged was the use of PPPbased comparative data, not just in IPCC documents, but more generally. In early 2005 we published another lengthy co-authored article: it was entitled 
'International Comparisons of GDP: Issues of Theory and Practice' ${ }^{5}$ Here we set out the case for PPP-based as opposed to exchange-rate-based figures, and reviewed the treatment of the issue in various places, including a range of international agencies as well as in the IPCC process. From our standpoint, the results of our survey were sobering. Aside from the UNDP, as mentioned above, none of the agencies appeared free from criticism. Further, we noted (82) the cases of several leading [economists] whose ... opinions, though not necessarily identical or consistent with one another, are at variance with what is laid down in SNA93'.

In this context, one of Ian's personal targets, with good reason, was the World Bank; and I still have on my files some email exchanges which he initiated, and which do little credit to the Bank staff members concerned. I also have a long letter from Ian to Dr Pachauri, dated 4 July 2004, which begins by saying 'I am awaiting your substantive reply to my letter to you of 20 April'. I believe that this letter, like its predecessor, and together with a successor dated 30 July and a further letter sent in November 1995, all went without response. From early 2004 onwards, Ian was increasingly treated in a number of official circles, not as a serious professional with a distinguished record, but as a tedious nuisance.

By this time, a disturbing reality was being brought home to us. It was increasingly apparent that in relation to the use and rationale of PPP-based cross-country comparisons it was we, rather than the scenario builders and their kind, who were in a minority. Our initial presumption, that SNA 1993 and the position laid down in it were widely known and generally endorsed by economists and other interested professionals, was revealed as a misapprehension. As will appear below, it was not our only misapprehension.

\section{Lord Lawson and the House of Lords Select Committee}

Early in 2004 our joint cause acquired a notable ally, when I convinced a former Chancellor of the Exchequer, Nigel (Lord) Lawson, that climate change issues deserved his serious attention. Lawson has been, and continues to be, a leading and influential contributor to the debate. In 2007 he brought out a book on the subject, ${ }^{6}$ and in early 2009 he established in London a think-tank called the Global Warming Policy Foundation, the declared object of which is 'to restore balance and trust to the climate change debate'. The Foundation's news service,

5 World Economics, Vol. 6 No. 1, 2005.

6 In Defence of Reason: A Cool look at Global Warming, Duckworth Overlook. The 2009 paperback edition incorporates some changes, and includes an extended afterword. In a review of the first edition in the Financial Times (14 April 2008) Clive Crook described it as a 'splendid book'. 
reports and briefing papers have made a solid contribution to that debate, which Ian would have welcomed and supported: he might well have become a GWPF author.

Lawson was (as he still is) a member of the House of Lords Select Committee on Economic Affairs, and early in 2005 the Committee chose as its next subject of inquiry the economics of climate change: its report on the subject appeared in July of that year. Both Ian and I, separately, submitted memoranda of evidence to the Committee. Ian's submission focused on the defects of the scenarios. He wrote:

In this submission I draw attention to eight further errors in the SRES and/or in the responses of the SRES Teams to our critiques, in addition to those identified in our previous papers. My purpose is to provide additional evidence in support of the view that the IPCC should not be accepted as the authoritative source of information on the economic aspects of climate change.

In its report, the Select Committee expressed 'significant doubts about some aspects of the IPCC's emissions scenario exercise' and 'some concerns about the objectivity of the IPCC process'. They also called for 'much stronger Treasury involvement' in the analysis of mitigation costs. These conclusions were welcome from our point of view, as also was what they said (in paragraph 53 of the report) about the work of Castles and Henderson, viz.: 'We consider that they have performed a public service' ${ }^{7}$

The Select Committee had included five former Cabinet ministers, a former Financial Secretary to the Treasury, a former Governor of the Bank of England, a noted professor of economics, and the distinguished biographer of JM Keynes. Its membership was drawn from all three political parties, as well as from crossbenchers. Its Specialist Adviser for this exercise was one of the world's leading environmental economists, the late David Pearce. Its report was unanimous. In view of these facts, one might have supposed that the report would be taken seriously in British official circles. Any such notion was dispelled when the then government's wholly dismissive response appeared, in November 2005. I wrote of this document, in a published commentary, that it 'is itself an illustration of those features of the IPCC process and milieu which prompted the Committee's concerns'.8

7 House of Lords Select Committee on Economic Affairs, 2nd Report of Session 2005-06, The Economics of Climate Change, Volume I: Report, Volume II: Evidence. The Stationery Office, 2005.

8 Government Response to the Economics of Climate Change, printed in November 2005 as an Appendix to the Select Committee's report. My critique of it was published in Energy and Environment, Vol. 17 No. 1, 2006. 
The two British government departments concerned, the Department of Environment, Food and Rural Affairs (DEFRA) and Her Majesty's Treasury, had submitted a joint memorandum of evidence to the Select Committee. Two matters of detail arising from this document are worth noting here as symptomatic:

- In the memorandum the two departments said that: 'When the debate first emerged we provided the IPCC with funds so that David Henderson could attend a meeting to discuss the issues with IPCC modellers'. Though presumably made in good faith, this was not a truthful statement.

- In August 2005 Ian sent a long email letter to the then Director, Climate Change and Environmental Risk in DEFRA, commenting on a number of mistakes and misapprehensions in the memorandum's references to our work. So far as I know, he received no response.

\section{Wider aspects}

Initially, as I have noted, Ian and I had chiefly focused on economic and statistical aspects of work undertaken and published under IPCC auspices. But as time went on, our involvement broadened in ways that we had neither planned nor anticipated. The following quotation, taken from a piece which I wrote in June 2010, fits Ian's case as well as my own:

Increasingly, and unexpectedly, I have become critical of the way in which issues of climate change have been viewed and treated by governments across the world. In particular, I have become a critic of the official expert advisory process which governments have created and continue to rely on, within which the main single element is the work of the IPCC as reflected in its successive Assessment Reports. Over the past 22 years governments everywhere, and a great many outside observers too, have put their trust in the expert advisory process as a whole and the IPCC process in particular. I have come to believe that this widespread trust is unwarranted. ${ }^{9}$

Among the episodes and publications that influenced us in this direction, from the end of 2003 onwards, I would mention in particular the evidence presented, both separately and in concert, by Stephen McIntyre and Ross McKitrick. Their writings, and later those of David Holland, not only placed in question widely accepted and influential results of IPCC-related work in climate science, but also exposed serious professional flaws in the conduct of that work. ${ }^{10}$ Ian

9 This is an excerpt from evidence that I submitted to the Inter-Academy Council Review of the IPCC.

10 There is an array of possible references here: Ross McKitrick's website is a good source. Some leading issues, first raised by McIntyre and McKitrick, were well reviewed in David Holland's 2007 article, 'Bias and 
became an occasional and respected contributor to McIntyre's well known blog, Climate Audit. The annex to this present paper summarises, from a later and more complete perspective, the grounds for questioning the advisory process that we both came to hold.

This extension of Ian's involvement, well beyond the specific technical issue which had initially brought him into the climate change debate, was not at all surprising: it was very much in character. His participation in that debate has to be seen, not as an isolated and eccentric late-in-life venture, but rather as a further manifestation, an extra dimension, of his established professional views and outlook. In particular, a prominent element in his thinking had long been a rejection of resource and environmental pessimism especially on the part of leading scientists: an example is his published article of 2001 entitled 'Scientists, Statisticians and the Prophets of Doom', where he also criticised what he called 'the enraged reaction' of some scientific reviewers to Bjorn Lomborg's book, The Skeptical Environmentalist. The climate change debate provided Ian with a further and continuing series of variations on what were for him the familiar themes of bias, over-presumption and mishandling of economic issues in some scientific circles. In this connection, I feel sure that he would have been greatly impressed, as I have been, by an outstanding soon-to-be published book, entitled The Age of Global Warming: A History, by Rupert Darwall. ${ }^{11}$

For both of us, this broadening of our concerns, beyond economic aspects, led to a development which I at any rate had not anticipated, and which for some time I failed to notice or suspect. In becoming increasingly preoccupied with the defects (as we saw them) of the official expert advisory process as a whole, including the treatment of climate science, we unwittingly separated ourselves from the majority of economists, whether in official positions or the academic world, who had come to hold views on climate change issues. The first intimations of this unforeseen divorce from the profession in general made themselves apparent in early 2006. The occasion was the Stern Review.

\section{Reviewing the Stern Review}

At the time of the House of Lords Select Committee report, and for a while afterwards, Ian and I kept to and reiterated our key recommendation, that the central economic departments of state - treasuries, finance ministries, and in the US, the Council of Economic Advisers - should become actively involved in

Concealment in the IPCC Process' (Energy and Environment, Vol. 18 No. 7-8); and the main single issue forms the subject of Andrew Montford's book, The Hockey Stick Illusion: Climategate and the Corruption of Science' (Stacey International, 2010), which is itself extensively referenced.

11 The book is due to be published in London in March 2013 by Quartet Books. 
the climate change debate. We noted with satisfaction that the same point was made, in relation to Her Majesty's Treasury, by Nigel Lawson during the Select Committee inquiry, when evidence was being given by the Treasury. He said that:

In my time at the Treasury as Chancellor it would have been unthinkable for the Treasury not to spend quite a lot of time on a serious economic analysis of an issue as important as this.

Ian and I presumed, and I think that Lawson too expected, that our shared arguments and concerns would gain support in so far as economists in general, and those in official positions in economic ministries and international agencies in particular, became more closely involved. This was our second misapprehension. We were soon to be given a forcible reminder of that well known cautionary advice: 'Be careful what you wish for'.

In July 2005 the then UK Prime Minister (Tony Blair) and Chancellor of the Exchequer (Gordon Brown) commissioned a top Treasury official, Sir Nicholas (now Lord) Stern, to lead a team to prepare a full-scale report on the economics of climate change. One result of this decision was that Ian and I once again became joint authors, in two separate journal articles, though in both cases as members of a larger group.

The Stern Review appeared in October 2006, while the printed volume, with an additional postscript, was published in early 2007. ${ }^{12}$ However, as early as January 2006 three interconnected documents had been issued as first fruits of the Review. They comprised a discussion paper entitled 'What Is the Economics of Climate Change?'; a public lecture by Stern with the same title; and a Technical Annex on 'The science of climate change'. The lecture was published in June 2006 as a lead article in World Economics; and towards the end of that same issue, the journal carried two related pieces arising from it: first a critique of the lecture and of its two accompanying texts; and second, a response by Stern himself. The critique was authored by a team of nine like-minded economists which I put together, and which included both Ian and Lord Lawson. (The other signatories comprised another member of the House of Lords Select Committee on Economic Affairs, Robert Skidelsky, together with Ian Byatt, Ross McKitrick, Julian Morris, Alan Peacock and Colin Robinson.) $)^{13}$

Looking back now, I can see that our short (six-page) article, which I have only once seen referred to, effectively broke new ground. This was because

12 Nicholas Stern and other authors, The Economics of Climate Change: The Stern Review, Cambridge University Press. 2007.

13 Nicholas Stern, 'What Is the Economics of Climate Change?'; 'Ian Byatt et al., 'Climate Change: The Stern Review “Oxonia Papers"'; Nicholas Stern, 'Reply to Byatt et al.' World Economics, Vol. 7 No. 2, 2006. 
we authors, economists though we were, did not direct our main critique to economic issues. Our opening thesis was that 'the treatment of scientific aspects in these documents is unbalanced'; and later in the article we held that the treatment by Stern and his associates was also at fault, first, in accepting uncritically both the procedures and the outcomes of the IPCC process, and second, in disregarding published work which had put that process in serious doubt. In our final paragraph we said (150) that:

By taking as given hypotheses that remain uncertain, assertions that are debatable or mistaken, and processes of inquiry that are at fault, the Review has put itself on a path that can lead to no useful outcome.

In his reply to this piece, Stern began by contesting our opening thesis. He set out reasons for holding (154) that 'The overwhelming body of evidence leaves no doubt that the threat of climate change is real and serious'. Thus the status and interpretation of the scientific evidence emerged, I think for the first time, as an issue on which economists were divided.

When the Review itself appeared, we returned to the fray. I was able to reconvene our economic group, again including Ian; and I also put together, flanking the economists, a separate team of scientists and engineers: it comprised, Robert Carter, Chris de Freitas, Indur Goklany, David Holland and Richard Lindzen. As a result, two linked review articles, one scientific and the other economic, were published in World Economics (Vol. 7 No. 4) at the end of 2006, under the heading of 'The Stern Review: A Dual Critique'. In a joint introduction to the two articles, representing all 14 authors, we wrote (166):

In relation to both scientific and economic issues, we question the accuracy and completeness of the Review's analysis and the objectivity of its treatment.

The economic critique was the last publication in which Ian and I appeared as joint authors, and it featured an annex entitled 'The Stern Review and the IPCC Scenarios' which he had drafted.

\section{Our second misapprehension revealed}

The Stern Review was widely acclaimed across the world; and not surprisingly, academic economists were among the many who judged it favourably. For example, it was endorsed on publication by several leading economists including four Nobel prizewinners; and in Australia, the officially-sponsored Garnaut report of 2008 can be seen as a southern hemisphere counterpart of the Review, 
which it described as 'a landmark contribution' ${ }^{14}$ On the other side of the fence, a number of prominent economists have been strong critics of the Review, as we had been: in that respect, these were allies. ${ }^{15}$ However, there was and remains an important element of difference between our position and that of most of our fellow-critics of Stern. Few economists, whatever their views on Stern, have joined with us in emphasising, first, that prevailing scientific opinion in this area should not be taken as established, and second, that the official expert advisory process on climate change has revealed itself as seriously flawed. Most of the critics of Stern (and Garnaut), along with the many supporters, share a common point of departure which is not ours: they endorse, or at any rate take as given and not to be queried, prevailing scientific opinion which they are apt to refer to as 'the science'; and they do not question the official expert advisory process - or give consideration to what its critics have written. For this reason I class these supporters and critics of the Stern Review together, despite their often-profound disagreements, as upholders of generally received opinion. We dissenters, or non-subscribers to that received opinion, form a minority.

It is important to note that the professional majority here comprises not only academic economists but also an array of counterparts of theirs in the official world. This is to be expected, in so far as the views held by these officials reflect a broadly common position that their respective organisations have long taken on climate change issues: both national governments and the international agencies which are their creation have continued to subscribe to received opinion. Among the agencies, this is true of the IMF, the World Bank, the OECD (including, alas, my former Department), the International Energy Agency, the EBRD and the European Commission, not to mention the UN Secretariat, UNCTAD, the UNDP, the UNFCCC and the UN Environment Program: in all of these, it would be hard to find economists who hold, and are ready to voice, dissenting views. ${ }^{16}$ The same applies within those agencies' member governments. What is especially telling is that the treasuries and finance ministries, on which Ian and I had pinned our hopes, have to be classed among the official upholders, as indeed had been the case from the start. Thus our initial expectation of wide and firm support from fellow-economists, and from departments and agencies with economic responsibilities, was in due course exposed as illusory. That situation still pertains today. It remains our second misapprehension.

14 The Garnaut Climate Change Review of 2008 was followed by The Garnaut Review 2011, likewise published by the Cambridge University Press. I commented on the published first draft of the report in a piece entitled 'Climate Change Issues: An Australian Contribution to the Debate' (World Economics, Vol. 9 No. 3, 2008).

15 A recent searching critique of the Review, published in 2012 by the Global Warming Policy Foundation, is 'What Is Wrong with Stern?, by Peter Lilley MP, a former UK cabinet minister.

16 I published a critique of the IMF's treatment of climate change issues, under the heading of 'OverPresumption and Myopia', in June 2008 (World Economics, Vol 9 No 2). 


\section{Voicing dissent}

After becoming fully attuned to our minority status, I published a long article in World Economics in early 2009 entitled "Economists and Climate Science: A Critique'. In the following year I returned to the theme in the pages of the quarterly Newsletter of the Royal Economic Society, where I was able to take account of the so-called 'Climategate' and 'Glaciergate' affairs and their sequel, all of which had provided further evidence of unprofessional conduct in relevant scientific circles. ${ }^{17}$

This latter article appeared only after Ian's death. However, I believe that he would have agreed fully with the following two excerpts from it. I quote them now despite their length, because I feel that here I was speaking for us both.

\section{First excerpt}

In a recent paper, I presented a critique of positions taken by a range of prominent economists of varying shades of green who were upholders of received opinion. I commented there on the Stern Review; on its Australian counterpart, the officially commissioned Garnaut report; on papers by Dieter Helm, William Nordhaus, and Martin Weitzman; and on the treatment of climate change issues by the IMF. (I could now add the World Bank, the International Energy Agency, and the OECD Secretariat). I charge this impressive array of authors and agencies with three interrelated failings: over-presumption, credulity and inadvertence:

- Over-presumption, in accepting too readily that received opinion on global warming is firmly grounded on scientific findings which can no longer be seriously questioned. In so doing, they are treating as established facts what should be viewed as no more than working hypotheses which have won considerable expert support;

- Credulity, through placing unwarranted trust in a flawed official expert advisory process, and

- Inadvertence, in that they have disregarded published evidence, evidence whichthey are competent to weigh and evaluate, which puts that process in serious question.

The latter two aspects, the credulity and the inadvertence, go together. Economist upholders, both in the groves of academe and around the corridors of power, have not woken up to the ways in which the official

17 'Climate Change Issues: New Developments in a 20-Year Context', Royal Economic Society Newsletter, October 2010. 
expert advisory process, and the IPCC process as its leading element, have been revealed as professionally not up to the mark. Hence there is a missing dimension in their treatment of policy aspects: they have not caught on to the need to strengthen the basis of policy, by making the advisory process more objective and professionally watertight.

\section{Second excerpt}

.. given what is at stake economically, a responsibility, so far unrecognised, rests on the central economic departments of state on treasuries, ministries of finance and economics and, in the US, the Council of Economic Advisers.

I am myself a former Treasury official; and much later, as head of what was then the Economics and Statistics Department in the OECD Secretariat, I had close dealings over a number of years with the central economic departments in OECD member countries. I have been surprised by the failure of these agencies to go more deeply into the evidence bearing on climate change issues, their uncritical acceptance of the results of a process of inquiry that is so obviously biased and flawed, and their lack of attention to the well-founded criticisms of that process that have been voiced by independent outsiders - criticisms which, I think, they ought to have been making themselves. A similar lack of resource has characterised the Research Department of the IMF and the Economics Department of the OECD... In all these official bodies with economic responsibilities, there has been a conspicuous failure of due diligence.

\section{Wider aspects revisited}

These criticisms of many fellow-economists reflected the broader concerns that Ian and I - and others too - had come to hold about the official handling of climate change issues across the world. In that broader context, here is an excerpt from an article of mine which first appeared in late 2011. Here again I believe that I was speaking for Ian as well as myself:

In relation to climate change issues, governments in general, and the OECD member governments in particular, have locked themselves into a set of procedures, and an associated way of thinking - in short, a framework - which both reflects and yields over-presumptive conclusions which are weighted towards alarm. They have done so through a worrying combination - of credulity and inadvertence on the part of responsible lay persons, and of chronic bias and professional underperformance on 
the part of trusted experts and expert bodies. In this whole episode, the capacity of human societies today to arrive at well founded conclusions and decisions has been placed in question. ${ }^{18}$

\section{Last contacts}

The last time that I saw and talked with Ian was in March 2007, on a visit to Canberra. (During that visit, by the way, I was invited by the Treasury to speak at a well-attended and exceptionally well-organised seminar: it is a pleasure to thank once again those who were responsible for that invitation). In preparing this paper, I found on my files a number of personal emails from Ian which he had sent me after our final Canberra meeting. Most of these took further the issue of PPP-based versus exchange-rate-based cross-country comparisons, where Ian continued to follow attentively developments on the international scene. Two of the emails, dating from 2008, respectively found fault with the way in which the issue was being handled in the IMF and the International Energy Agency.

Of these latter-year messages from Ian, two were prompt and well-crafted responses to requests on my part for comment. As to the first, I had sent him an article of mine which came out in June 2007, where I had quoted, and now drew to his attention, to an excerpt from a speech in the House of Lords by Richard Layard, a well known London School of Economics professor of economics and a member of the House of Lords Select Committee. Layard had referred to the many statements on climate change issues by national scientific academies, and said that he could not 'really see how non-scientists can take a different view unless we want to question their motivation'. Ian concluded his comments on this argument by writing: 'Examination of the contents of statements by national academies confirms your view that the support of these bodies for the IPCC should not be regarded as decisive and is by no means above question'.

The last personal message that I have on file dates from July 2008. It was prompted by my sending Ian a series of arguments against the use of PPP-based comparisons which had been sent to me by an eminent American professor of economics. Ian dealt with each argument in turn in masterly fashion. Reading those pages, it was saddening for me to be reminded that I had lost forever both a true friend and a much-valued continuing source of ideas, information and advice.

18 The piece from which this passage is taken forms a chapter in a volume of essays in honour of the President of the Czech Republic, Vaclav Klaus (Today's World and Vaclav Klaus, edited by Jiri Brodsky and published in 2012 by Fragment). The piece first appeared with a different title in the Australian journal Quadrant, and in this form President Klaus posted it on his personal website. 


\section{A final glimpse}

In preparing this present paper, and looking back at our shared thoughts and activities over more than a decade, I asked myself whether in fact Ian counted as, and would have described himself as, an economic liberal. I feel confident that the answer is Yes; but rather than going into the question directly I will end with a quotation from an original and perceptive article, very characteristic of its author, that Ian wrote and sent to me in (I think) the year 2000. The theme of the article, a favourite one of his, was unwarranted pessimism and collectivist prescriptions on the part of eminent scientists and political leaders who unwisely put their trust in such presumed experts. In this case, the pertinent examples he gave were from Britain in the years after World War II. One of the scientists involved was Sir Henry Tizard, then Chief Scientific Adviser to the Ministry of Defence and chairman of an official Advisory Council on Scientific Policy. The final two paragraphs of Ian's paper, as also of this paper of mine today, read as follows:

... Tizard told the 1948 British Association meeting that "All social progress, such as spread of education, promotion of health, opportunities for leisure and healthy recreation, must depend on the power of technology to increase the productivity of industry". Economist [Ludwig] Erhard, architect of Germany's "economic miracle", recognised the vital role of another factor: effectively functioning markets. It is difficult to resist the conclusion that much of the difference in the material achievement of the two countries in the early post-war decades can be attributed to the relative influence of these mindsets.

It would be overly simple to extend the comparison, and attribute all of the changes in the relative economic performance of Britain and Germany through the nineteenth and the twentieth centuries solely to the relative strength in each country of liberal ideas, both in the intellectual and the political spheres. But the pervasive influence of such ideas upon "the material foundations of the liberty and welfare of all peoples" should not be underestimated.

\section{Annex: A Flawed Process}

(The following article by David Henderson appeared in The Australian on 16 February 2010, under the title 'Climategate is Just the Tip of the Iceberg'.)

Two recent episodes have given rise to concerns about the quality and reliability of received expert advice on climate change.

First is the unauthorised release of a mass of email exchanges from the server of the Climatic Research Unit at the University of East Anglia: the contents have put in question the conduct of CRU scientists and some of their correspondents. 
Second is the discovery that statements made in the fourth and most recent Assessment Report (AR4) from the Intergovernmental Panel on Climate Change (IPCC) were based on sources which should not have been given weight. In relation to what was said about Himalayan glaciers, the IPCC has issued a formal admission of error.

The concerns raised by these episodes are well founded. However, 'Climategate' and 'Glaciergate' are not to be viewed in isolation. They are instances of a more fundamental and deeply entrenched phenomenon.

In relation to climate change issues, the established official expert advisory process, which governments have commissioned and relied on, has shown itself, over many years, to be not professionally up to the mark. The situation is one of unwarranted trust.

The main headings of unprofessional conduct within the process, all identified and documented before the recent revelations, have been:

- Over-reliance on in-group peer review procedures which do not serve as a guarantee of quality and do not ensure due disclosure.

- Serious and continuing failures of disclosure and archiving in relation to peer-reviewed studies, which the IPCC and member governments have drawn on.

- Continuing resistance to disclosure of basic information, which reputable journals insist on as a precondition for acceptance. (In the CRU emails, participants discuss a range of arguments, pretexts and devices that could be used to fend off disclosure, including the deletion of emails containing material that had been sought under FOI requests - requests that were made only because authors had not followed accepted scholarly procedures).

- Basic errors in the handling of data, through failure to consult or involve trained statisticians.

- Failure to take due account of relevant published work which documented the above lapses, while disregarding IPCC criteria for inclusion in the review process.

- Failure to take due note of comments from dissenting critics who took part in the preparation of AR4.

- Resisting the disclosure of professional exchanges within the AR4 drafting process, despite the formal instruction of member governments that the IPCC's proceedings should be 'open and transparent'. And last but not least

- Failure on the part of the IPCC and its directing circle to acknowledge and remedy the above deficiencies. 
In the light of 'Glaciergate', one could add to the above list 'reliance on worthless (non-peer-reviewed) sources'. But mere insistence on peer review would leave in place the other basic flaws.

Comprehensive exposure of these flaws has come from a number of independent commentators. Particular mention should be made of two Canadian authors, Stephen McIntyre and Ross McKitrick: both separately and in joint publications, going back to 2003, they have made an outstanding contribution to public debate. Together with a perceptive British critic, David Holland, they are the subject of unfavourable references in the CRU emails. However, their work and that of other informed critics has been disregarded by governments, and by most commentators in academic journals and the media alike.

The glaring defects in the expert advisory process have gone unacknowledged and unremedied by what I call the environmental policy milieu. This high-level failure, as also the defects themselves, have resulted from chronic and pervasive bias. Right from the start, members of the milieu, and of the IPCC's directing circle, have been characterised by what has been well termed 'pre-commitment to the urgency of the climate cause'.

Although the IPCC in particular is now under fire, this is too restricted a focus. It is true that the Panel's work forms the leading element in the official expert advisory process. But the basic problem of unwarranted trust goes further: it extends to the chronically biased treatment of climate change issues by responsible departments and agencies which the Panel reports to, and in nationally based organisations which they finance (such as the CRU).

It is not just the environmental policy milieu that is to blame for the mishandling by governments of climate change issues. As a former Treasury official and international civil servant, I have been surprised by the failure of economic departments in OECD member countries to audit the evidence bearing on climate change issues, their uncritical acceptance of the results of a process of inquiry which is so obviously biased and flawed, and their lack of attention to the criticisms of that process which have been voiced by independent outsiders - criticisms which they ought to have been making themselves. A similar lack of resource has characterised the Research Department of the IMF and the Economics Department of the OECD. In all these departments and agencies, there has been a conspicuous failure of due diligence.

The chief moral to be drawn is simple. In an area of policy where so much is at stake, and so much remains uncertain and unsettled, policies should be evolutionary and adaptive, rather than presumptive as they are now; and their evolution should be linked to a process of inquiry and review which is more thorough, balanced, open and objective than has so far been the case. 